\title{
Perancangan Sistem Informasi Pengolahan Data Penjualan Secara Kredit dan Controlling Stock Dengan Menerapkan Metode Backorder Pada Toko Master Menggunakan Bahasa Pemrograman Java dan Database MySql
}

\author{
J. Prayoga \\ Universitas Dharmawangsa Medan \\ E-mail: yoga@dharmawangsa.ac.id
}

\begin{abstract}
Abstrak
Telah melakukan penelitian di Master Store, di mana masalah yang digunakan sebagai dasar dalam penulisan ini adalah sistem pemrosesan data penjualan secara kredit dan pengendalian stok. Melalui proses pengamatan langsung dari lapangan telah diperoleh kelemahan dari sistem yang ada. Meskipun tidak sepenuhnya tetapi lebih mengarah pada masalah tertentu, diharapkan dapat memberikan kontribusi yang signifikan bagi para pengguna sistem. Penulis merancang sistem informasi pemrosesan data penjualan secara kredit dan pengendalian stok berbasis Java Master Store, karena dengan sistem informasi ini akan lebih cepat, tepat, dan akurat. Dalam merancang sistem baru ini menggunakan bahasa pemrograman Java dan database MySQL, dengan desain sistem baru ini penulis mewujudkan sistem pemrosesan data penjualan secara kredit dan stok pengendali yang efisien di Master Store.
\end{abstract}

Kata kunci: Pemrosesan Data Penjualan Kredit Dan Mengontrol Saham, JAVA, MySQL

\begin{abstract}
Had done the research on the Master Store, where the problems are used as the basis in writing this is a system of data processing sales on credit and controlling stock. Through the process of direct observation of the field has gained the weaknesses of the existing system. Although not entirely but more directed to a specific problem, it is expected to contribute significantly to the users of the system. The author designed the information system of data processing sales on credit and controlling stock based on Java Master Store, because with this information system will be faster, precise, and accurate. In designing this new system used the Java programming language and MySQL database, with the design of this new system the authors embody the system of data processing sales on credit and efficient controlling stock on the Master Store.
\end{abstract}

Keywords: Credit Sales Data Processing And Controlling Stock, JAVA, MySQL

\section{Pendahuluan}

Dalam dunia perdagangan seperti saat ini dengan iklim persaingan yang semakin ketat, penyajian informasi yang akurat, cepat, dan tepat adalah modal utama dalam menghadapi persaingan. Perkembangan ilmu pengetahuan dan teknologi telah memperlihatkan kemajuan yang pesat untuk dapat diaplikasikan disemua bidang. Salah satu contoh kemajuan itu adalah terciptanya komputer, dimana komputer mempunyai banyak kegunaan dan kepraktisan kerja yang sangat tinggi untuk mengolah data yang rumit dan jumlah yang banyak.

Pada perusahaan yang ingin bersaing dan mengejar keuntungan yang besar, maka komputer merupakan alat bantu yang sangat bermanfaat dalam proses kegiatan perusahaan, termasuk proses penyediaan informasi-informasi merupakan sumber data yang diperlukan oleh berbagai pihak dalam sebuah perusahaan, baik pihak internal maupun pihak ekternal perusahaan, salah satu informasi yang sangat penting adalah informasi tentang penjualan kredit dan persediaan barang.

Pengolahan data penjualan kredit dan persediaan (Stock) barang pada Toko Master masih dilaksanakan secara manual sehingga kemungkinan terjadinya kesalahan dalam memproses data pejualan dan persediaan barang sangat besar serta menyulitkan untuk mengetahui penjualan kredit dan persediaan barang pada Toko Master tersebut. Informasi mengenai penjulan kredit dan stock barang ini sangat penting karena proses pembelian maupun penjualan berawal dari sistem ini, untuk itulah sangat diperlukan informasi yang akurat mengenai sistem pengolahan data ini. Selain itu toko 
Master sering mengalami suatu kondisi dalam pendistribusian barang, dimana barang yang dipesan tidak atau belum dapat disediakan baik seluruhnya ataupun sebagian. Hal ini mengakibatkan terganggunya transaksi penjualan sehingga menurunkan omset penjualan yang berimbas kepada kerugian.

Berkaitan dengan uraian di atas, perlu adanya sebuah cara atau metode yang dapat digunakan untuk mengendalikan persediaan. Salah satu metode yang dapat digunakan adalah metode pengendalian persediaan Backorder. Penggunaan kondisi backorder adalah untuk menentukan jumlah persediaan yang habis ketika adanya permintaan dari konsumen yang tidak dapat dipenuhi atau dimana konsumen berhak memilih untuk menunggu pesanan dapat dipenuhi lagi atau sebaliknya (Lina Budiati, 2014).

Berdasarkan latar belakang yang telah diuraikan diatas dan untuk membantu menciptakan suatu sistem persediaan barang yang lebih tepat, cepat dan akurat, maka penulis tertarik untuk membahas permasalahan ini dalam skripsi dengan judul "Perancangan Sistem Informasi Pengolahan Data Penjualan Secara Kredit dan Controlling Stock Dengan Menerapkan Metode Backorder Pada Toko Master Menggunakan Bahasa Pemrograman Java dan Database MySql”.

\section{LANDASAN TEORI}

\subsection{Pengertian Sistem}

Sistem didefinisikan sebagai sekumpulann prosedur yang saling berkaitan dan saling berhubungan untuk melakukan suatu tugas secara bersama-sama (I Putu Agus Eka Pratama, 2014)

Sistem adalah sekelompok elemen-elemen yang terintegrasi dengan tujuan yang sama untuk mencapai suatu tujuan. Terdiri dari sejumlah sumber daya manusia, material, mesin, uang dan informasi. Sumber daya tersebut bekerja sama menuju tercapainya suatu tujuan tertentu yang ditentukan oleh pemilik atau manajemen. (Yakub, 2012).

Sistem adalah kumpulan atau himpunan dari unsur atau variabel-variabel yang saling terkait, saling berinteraksi, dan saling tergantung satu sama lain untuk mencapai tujuan (Hamim Tohari, 2013). Oleh sebab itu dalam membangun suatu sistem, kita harus paham betul konsep dasar sistem itu sendiri. Sebagaiman gambaran, jika sebuah sistem terdapat elemen yang tidak memberikan manfaat dalam mencapai tujuan bersama, maka elemen tersebut dapat dipastikan bukanlah bagian dari sistem.

\subsection{Elemen Sistem}

Ada beberapa elemen-elemen yang saling terkait dalam membentuk sebuah sistem, (Abdul Kadir, 2013) yaitu:

1. Tujuan

Setiap sistem memiliki tujuan ( $g o a l$ ), entah hanya satu atau banyak. Tujuan inilah yang akan menjadi motivasi yang mengarahkan sistem. Tanpa tujuan, sistem menjadi tak terarah dan tak terkendali. Tentu saja tujuan antara satu sistem dengan sistem lain berbeda-beda. Begitu pula yang berlaku pada sistem informasi. Setiap sistem informasi memiliki tujuan, tetapi dengan tujuan yang berbeda-beda. Walaupun begitu, tujuan utama yang umum ada tiga macam yaitu:

a. Untuk mendukung fungsi kepengurusan manajemen

b. Untuk mendukung pengambilan keputusan manajemen

c. Untuk mendukung kegiatan operasi perusahaan.

2. Masukan

Masukan (Input) sistem adalah segala sesuatu yang masuk yang masuk ke dalam sistem yang selanjutnya menjadi bahan untuk diproses. Masukan dapat berupa hal-hal berwujud (tampak secara fisik) maupun yang tidak tampak. Contoh masukann yang berwujud adalah bahan mentah, sedangkan contoh yang tidak berwujud adalah informasi (misalnya permintaan jasa dari pelanggan). Pada sistem informasi masukan dapat berupa data transaksi dan data non transaksi (misalnya surat pemberitahuan) serta intruksi. 
3. Proses

Proses merupakan bagian yang melakukan perubahan atau transformasi dari masukan menjadi keluaran yang berguna, misalnya informasi dan produk tetapi juga bisa hal-hal yang tidak berguna, misalnya sisa pembuangan atau limbah. Pada pabrik kimia proses dapat berupa pemanasan bahan mentah. Pada rumah sakit, proses dapat berupa aktivitas pembedahan pasien. Pada sistem informasi, proses dapat berupa suatu tindakan yang bermacam. Meringkas data, melakukan perhitungan dan mengurutkan data merupakan beberapa contoh proses.

4. Keluaran

Keluaran (Output) merupakan hasil dari pemrosesan. Pada sistem informasi, keluaran bisa berupa suatu informasi, saran, cetakan laporan, dan sebagainya.

5. Mekanisme pengendalian, dan Umpan balik

Mekanisme pengendalian (Controll Mekanism) diwujudkan dengan menggunakan umpan balik (feedback), yang mencerminkan keluaran. Umpan balik ini digunakan untuk mengendalikan baik masukan maupun proses. Tujuannya adalah mengatur agar sistem berjalan sesuai dengan tujuan. Dalam bentuk yang sederhana, dilakukan pembandingan antara keluaran sistem dan keluaran yang dikehendaki (Standart).

Untuk lebih jelasnya mengenai elemen sistem dapat dilihat pada gambar dibawah ini:

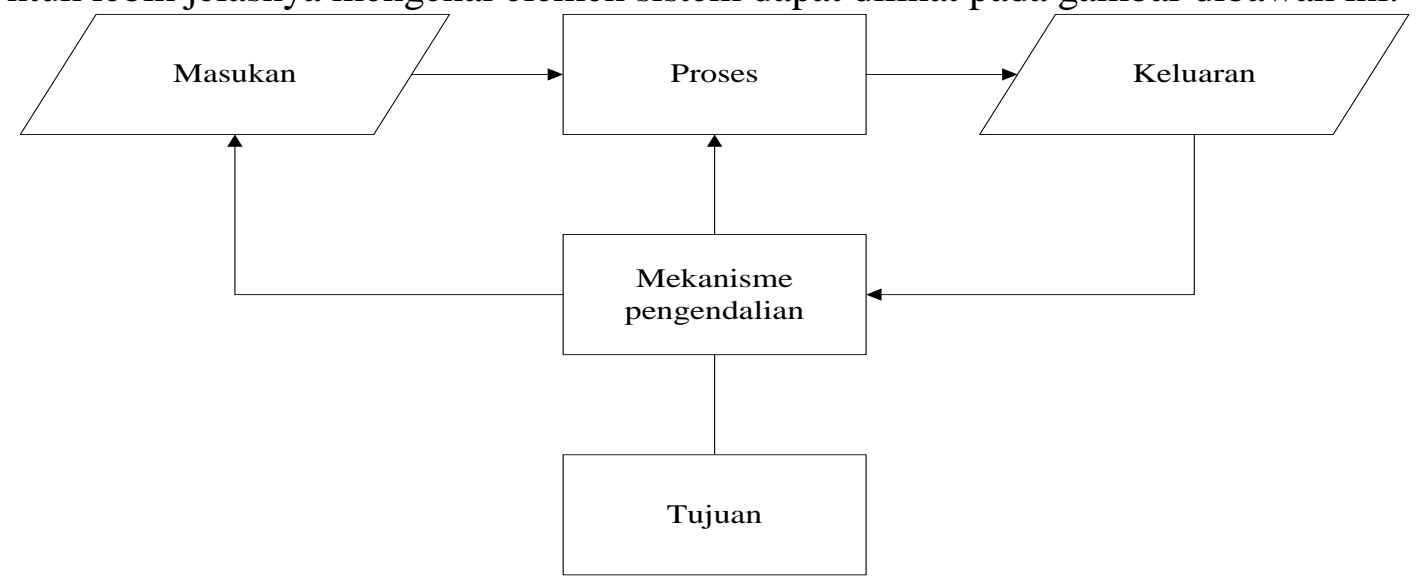

Sumber : (Abdul Kadir, 2013)

\section{Gambar 1 Sistem dan Elemen-elemenya}

\subsection{Pengertian Informasi}

Informasi di dalam sebuah perusahaan yang sangat penting untuk mendukung kelangsungan perkembangannya. Akibat bila kurang mendapatkan informasi, dalam waktu tertentu perusahaan akan mengalami ketidakmampuan mengontrol sumber daya, yang pada akhirnya akan mengalami kekalahan dalam bersaing dengan lingkungan pesaingnya.

Informasi merupakan hasil pengolahan data dari satu atau berbagai sumber, yang kemudian diolah, sehingga memberikan nilai, arti dan manfaat (I Putu Agus Eka Pratama, 2014)

Informasi (information) adalah data yang di olah menjadi bentuk lebih berguna dan lebih berarti bagi yang menerimanya atau data yang diprosessedemikian rupa sehingga meningkatkan pengetahuan seseorang yang menggunakan. Sistem apapun tanpa ada informasi tidak akan berguna, karena sistem tersebut akan mengalami kemacetan dan akhirnya berhenti. Informasi dapat berupa data mentah, data tersusun, kapasitas sebuah saluran informasi dan sebagainya. (Yakub, 2012).

Ada beberapa pengertian lain tentang informasi (Abdul Kadir, 2013), yaitu:

1. Menurut McFadden, dkk.

Informasi adalah data yang telah diproses sedemikian rupa sehingga meningkatkan kemampuan seseorang yang menggunakan data tersebut.

2. Menurut Shanon dan Weaver

Inforamasi adalah jumlah ketidakpastian yang dikurangi ketika sebuah pesan diterima. 
3. Menurut Davis.

Informasi adalah data yang telah diolah menjadi sebuah bentuk yang berarti bagi penerimanya dan bermanfaat dalam pengambilan keputusan saat ini atau masa yang akan datang.

Adapun proses transformasi data menjadi informasi dapat dilihat pada Gambar 2.2 berikut:

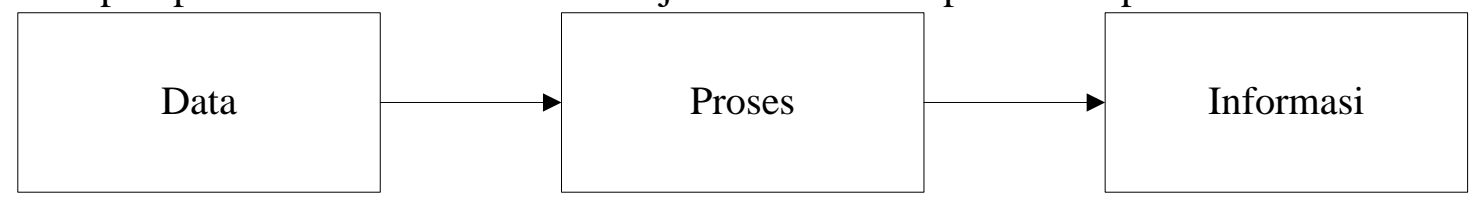

Sumber : (Abdul Kadir, 2013)

\section{Gambar 2 Transformasi Data Menjadi Informasi}

Untuk memperoleh informasi yang bermanfaat bagi penerimanya, perlu dijelaskan bagaimana siklus yang terjadi atau dibutuhkan dalam menghasilkan informasi. Pertaman-tama data dimasukan kedalam model yang umumnya memiliki urutan proses tertentu dan pasti, setelah diproses akan dihasilkan informasi tertentu yang bermanfaat bagi penerima sebagai dasar dalam membuat suatu keputusan atau melakukan tindakan tertentu.

Suatu Informasi dapat dikatakan benilai apabila telah memenuhi beberapa kriteria, yaitu akurat (acuracy), tepat waktu (timeliness), dan relevan (relevancce).

1. Akurat

Informasi yang dihasilkan harus bebas dari kesalahan-kesalahan. Akurat juga berarti informasi harus jelas mencerminkan maksudnya.

2. Tepat pada waktunya

Informasi tepat waktu, karena informasi merupakan landasan di dalam pengambilan keputusan di tingkat manajemen yang lebih tinggi.

3. Relevan

Informasi tersebut mempunyai manfaat untuk pemakainya, Relevansi informasi untuk setiap pemakai yang satu dengan yang lainnya berbeda.

\subsection{Pengertian Sistem Informasi}

Sistem informasi merupakan gabungan dari empat bagian utama. Bagian utama tersebut mencakup perangkat lunak (Software), perangkat keras (Hardware), Infrastruktur dan Sumber daya manusia (SDMM) yang terlatih. Keempat sistem utama ini saling berkaitan untuk menciptakan sebuah sistem yang dapat mengolah data menjadi informasi yang bermanfaat (I Putu Agus Eka Pratama, 2014)

Ada beberapa pengertian lain tentang sistem informasi (Abdul Kadir, 2013), yaitu:

1. Menurut Alter

Sistem Informasi adalah kombinasi antara prosedur kerja, informasi, orang dan teknologi informasi yang diorganisasikan untuk mencapai tujuan dalam sebuah organisasi.

2. Menurut Bodnar dan Hopwood.

Sistem Informasi adalah kumpulan perangkat keras dan perangkat lunak yang dirancang untuk mentransformasikan data kedalam bentuk informasi yang berguna.

3. Menurut Galinas, Oram, dan Weggins

Sistem Informasi adalah suatu sistem buatan manusia yang secara umum terdiri atas sekumpulan manual yang dibuat untuk menghimpun, menyimpan, dan mengelolah data serta menyediakan informasi keluaran kepada pemakai.

4. Menurut Hall.

Sistem Informasi adalah sebuah rangkaian prosedur formal di mana data dikelompokkan, diproses menjadi informasi, dan didistribusikan kepada pemakai.

5. Menurut Tuban, McLean, dan Wetherbe 
Sebuah sistem informasi mengumpulkan, memproses, menyimpan, menganalisis, dan menyebarkan informasi untuk tujuan yang spesifik.

6. Menurut Wilkinson

Sistem informasi adalah kerangka kerja yang mengkoordinasikan sumber daya (manusia, komputer) untuk mengubah masukan (input) menjadi keluaran (informasi),guna mencapai sasaran-sasaran perusahaan.

\subsubsection{Komponen Sistem Informasi}

dalam suatu sistem informasi terdapat komponen-komponen (Abdul Kadir, 2013), seperti:

1. Perangkat keras (Hardware): Mencakup piranti-piranti fisik seperti komputer dan printer.

2. Perangkat Lunak (Software) atau program: Sekumpulan instruksi yang memungkinkan perangkat keras untuk dapat memproses data.

3. Prosedur: Sekumpulan aturan yang diapakai untuk menwujudkan pemrosesan data dan pembangkitan keluaran yang dikehendaki.

4. Orang: semua pihak yang bertanggung jawab dalam pengembangan sistem informasi, pemrosesan, dan penggunanaan keluaran istem informasi.

5. Basis data (Database): Sekumpulan tabel, hubungan, dan lain-lainya yang berkaitan dengan penyimpanan data.

6. Jaringan komputer dan komunikasi data: sistem penghubung yang memungkinkan sumber dipakai secara bersamaan atau dapat diakses oleh sejumlah pemakai sistem.

\subsubsection{Macam-Macam Sistem Informasi}

Terdapat lima jenis sistem informasi yang dianggap dapat menunjang efektivitas dan efesiensi suatu perusahaan (Hamim Tohari, 2013). Lima jenis sistem informasi tersebut adalah sebagai berikut :

1. Sistem Infomasi Akuntansi

Sistem informasi akuntansi, yaitu sistem informasi yang menyajikan informasi yang dipakai oleh fungsi akuntasi. Sistem ini mencakup semua transaksi yang berhubungan dengan keuangan di sebuah perusahaan atau organisasi.

2. Sistem Informasi Manufaktur

Sistem informasi Manufaktur, yaitu sistem infomasi yang bekerja dengan sistem informasi lain untuk mendukung manajemen perusahaan dalam menyelesaikan masalah yang berhubungan prooduk atau jasa yang dihasilkan perusahaan.

3. Sistem informasi SDM

Sistem informasi SDM, yaitu sistem informasi yang digunakan oleh perusahaan khususnya dibagian personalia.

4. Sistem informasi keuangan

Sistem informasi keuangan, yaitu sistem informasi yang menyediakan informasi pada fungsi keuangan yang menyangkut keuangan perusahaan.

5. Siste infornasi pemasaran

Sistem informasi keuangan, yaitu sistem informasi yang menydiakan informasi yang dibutuhkan oleh fungsi pemasaran.

Sedangkan sistem informasi menurut kebutuhan manajemen dapat dibagi menjadi beberapa macam (Hamim Tohari, 2013) antara lain :

1. Tracsaction Processing System (TPS)

TPS adalah sistem informasi yang terkomputerisasi yang dikembangkan untuk memproses data-data dalam jumlah besar untuk transaksi bisnis rutin seperti daftar gaji dan inventarisasi.

2. Manajemen Informastion System (MIS)

MIS adalah sistem informasi yang menyajikan berbagai bentuk laporan yang diperlukan manajemen untuk analisis dan pengambilan keputusan. 
3. Decission Support System (DSS)

DSS adalah pengembangan SIM yang dilengakapi dengan kemaampuan analisis untuk menghasilkan beberapa alternatif pertimbangan keputusan atau informasi lain yang terkaitdengan suatu focus pengambilan keputusan sebagai penunjang keputusan yang akan tetap dilakukan oleh manajemen.

4. Executive Information System (EIS)

EIS membantu para eksekutif atau manajemen tingkat strategis dalam mengatur interaksi mereka dengan lingkungan eksternal, memberikan berbagai informasi yang diperlukan terkait dengan masalah-masalah strategis dan pengambilan sebagai keputusan yang tidak terstruktur.

5. Expert System (ES) atau Knowledge Work System (KWS)

ES adalah sistem informasi yang mengunakan ilmu, fakta dan teknik berpikir dalam pengambilan keputusan untuk masalah-masalah yang biasanya hanya dapat diselesaikan oleh para ahli atau pakar untuk bidang tertentu.

6. Office Automation System (OAS)

OAS mendukung pekerja data, yang biasanya tidak menciptakan pengetahuan baru elainkan hanya menganalisis informasi sedemikian rupa untuk menstranformasikan data atau memanipulasikannya dengan cara -cara tertentu sebelum membagi atau menyebarkannya.

7. Group Decision Support System (GDSS) atau Computer Supported Collaborative Work (CSSW).

GDSS adalah sistem yang digunakan untuk membuat keputusan semi-terstruktur oleh kelompok pengambil keputusan, mendukung berbagai konfigursi yang berbeda-beda baik secara hardware maupun software.

\section{Metodologi}

Agar dalam penulisan laporan ini terfokus dan tidak terlepas dari data dan informasi yang Agar dalam penulisan skripsi ini terfokus dan tidak terlepas dari data dan informasi yang berhubungan dengan pokok pembahasan maka penulis menggunakan beberapa metode penelitian untuk mendapatkan data-data tersebut.

1. Penelitan Lapangan(Field Research)

Penelitian langsung ke Toko Master untuk mengumpulkan data serta wawancara dengan salah seorang karyawan Toko Master.

2. Penelitian Kepustakaan (Library Reseach)

Penelitian dilakukan untuk mendapatkan data sekunder mengumpulkan data dengan cara membaca buku-buku atau literatur yang berhubungan dengan dengan masalah yang akan diteliti.

3. Penelitian Laboratorium (Laboratory Reseach)

Dalam hal ini digunakan hardware maupun software agar tujuan perancangan tercapai.

\section{ANALISA DAN HASIL}

Analisa sistem dapat didefinisikan sebagai penguraian dari suatu sistem informasi yang utuh kedalam bagian bagian komponennya dengan maksud untuk mengindentifikasi dan mengevaluasi permasalahan-permasalahan, kesempatan, hambatan, dan kebutuhan- kebutuhan yang diharapkan sehingga dapat diusulkan perbaikan- perbaikannya.

Dari hasil penelitian yang telah dilakukan baik dengan melakukan survey langsung ke Toko Master maupun tidak langsung, maka dapat diuraikan kerja sistem yang ada Toko Master. Dimana dalam pengolahan transaksi penjualan kredit dan pengolahan stock barang, Toko Master membutuhkan waktu yang lama dan kurang efisien karena masih belum optimalnya penggunaan komputerisasi dan analisa yang dilakukan secara manual. 
Adapun prosedur pengolahan data penjualan kredit dan pengolahan stock barang yang sedang diterapkan pada Toko Master adalah sebagai berikut:

1. Pelanggan memberikan permintaan barang kepada kasir.

2. Kasir melakukan pengecekan stock dan membuat faktur sebanyak 3 (tiga) rangkap. Rangkap 1 (satu) dijadikan arsip, rangkap 2 (dua) diberikan kepada pelanggan sedangkan rangkap 3 diberikan kepada Karyawan.

3. Berdasarkan faktur tersebut pelanggan membayar pelunasan piutang.

4. Kemudian Karyawan membuat laporan penjualan dan diserahkan kepada Pimpinan.

\subsection{Aliran Sistem Informasi Lama}

Adapun Aliran Sistem Informasi Toko Master yang lama dapat dilihat pada Gambar 3.

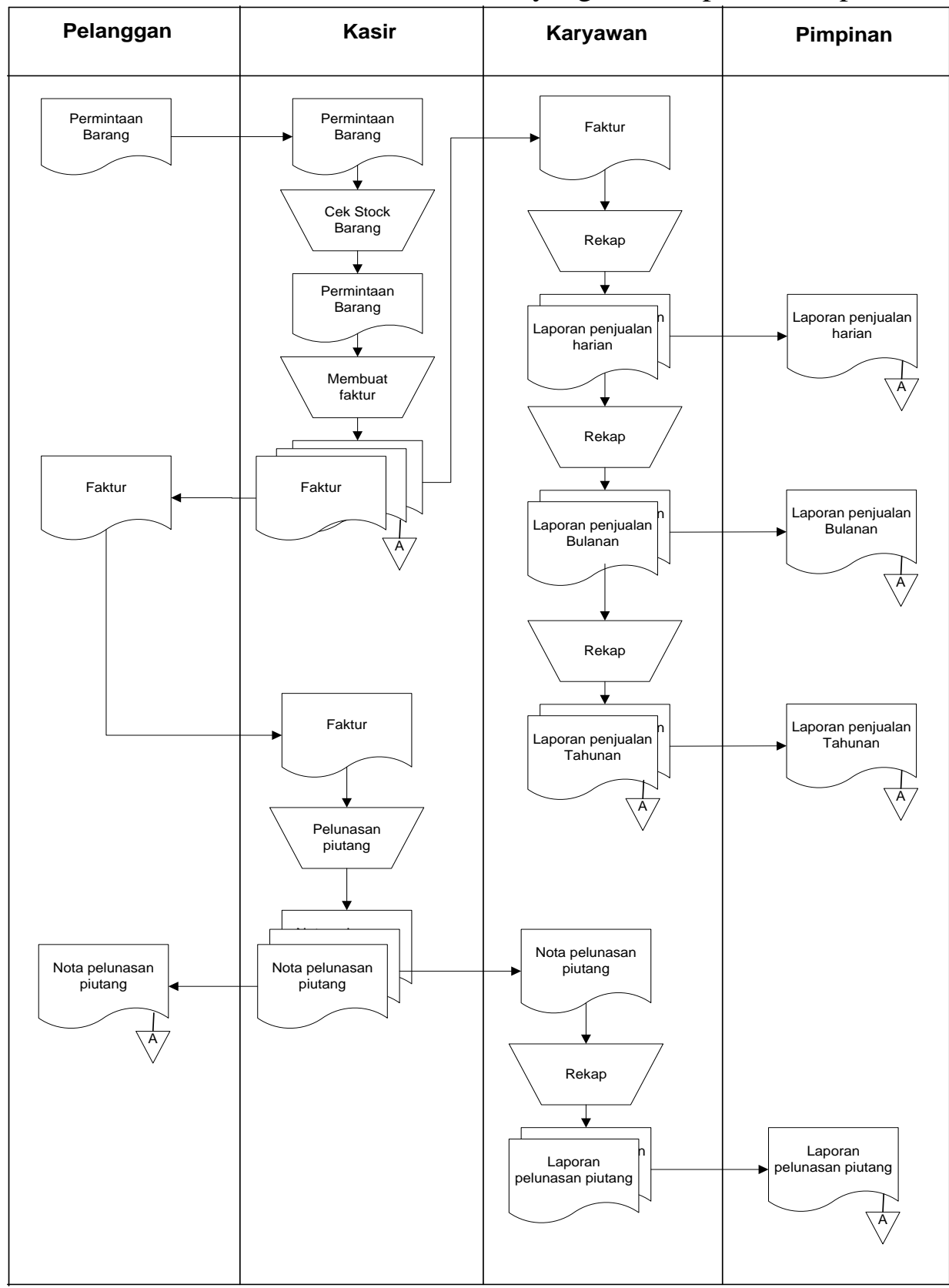

Gambar 3 Aliran Sistem Informasi (ASI) Lama 


\subsection{Desain Sistem Baru}

Perancangan sistem pada suatu organisasi haruslah berjalan sesuai dengan perkembangan organisasi, artinya sistem yang dirancang haruslah lebih baik bila dibandingkan dengan sistem yang lama, baik dalam segi efisiensi maupun dari segi hasil laporan yang dirancang. Desain sistem baru terdiri dari 2 (dua) bagian yaitu Desain Sistem Secara global atau desain sistem secara umum dan Desain Sistem Terinci atau desain sistem secara khusus.

Adapun Aliran Sistem Informasi (ASI) Baru dapat dilihat pada Gambar 3.4.

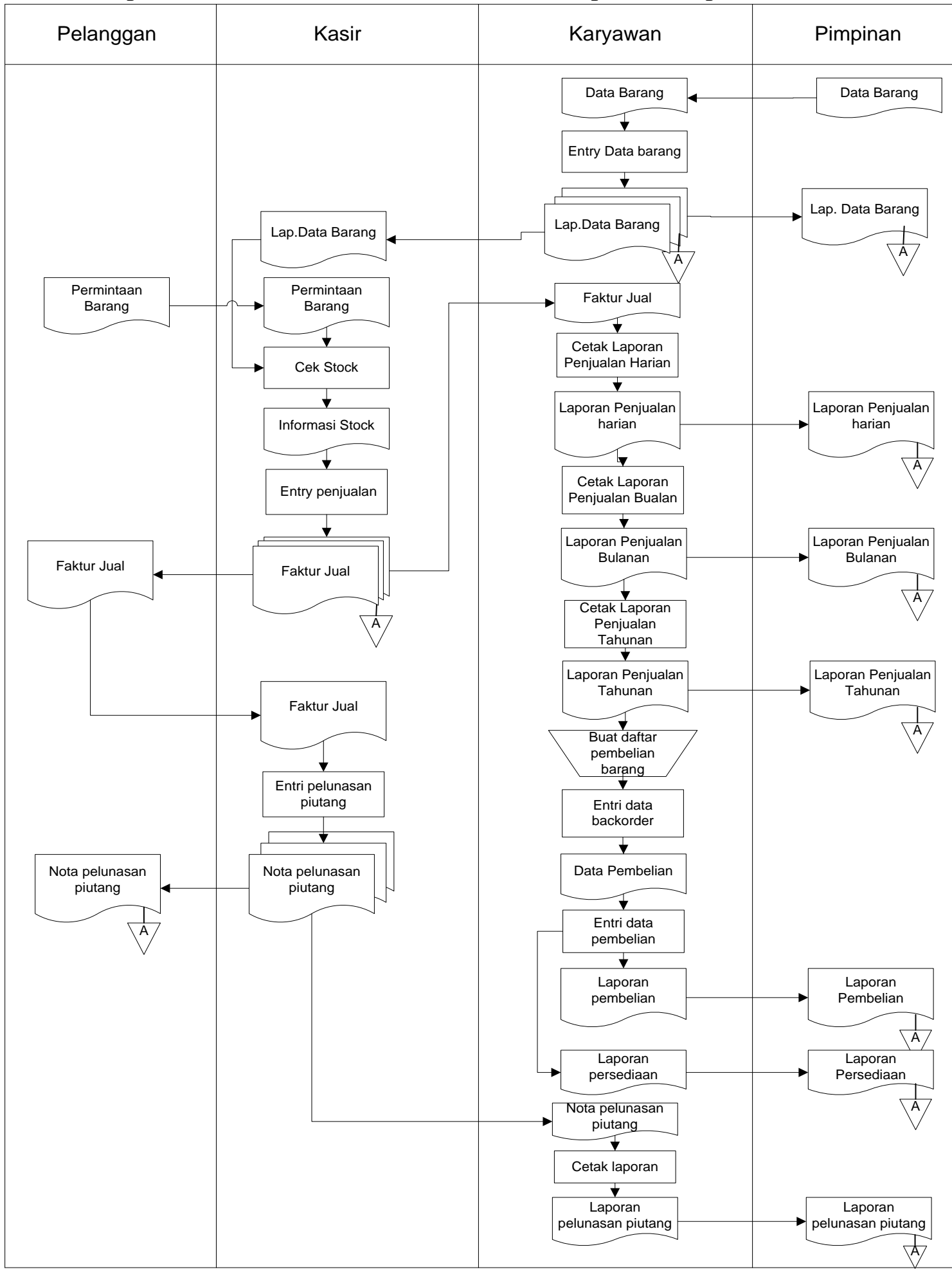

Gambar 4 Aliran Sistem Informasi (Asi) Baru 


\subsection{Context Diagram}

Context Diagram adalah gambaran umum tentang suatu sistem yang terdapat dalam suatu organisasi yang memperlihatkan batasan (boundry) sistem, adanya interaksi antara eksternal entity dengan suatu sistem dan informasi secara umum mengalir diantara entity dan sistem. Context diagram ini merupakan alat bantu yang digunakan dalam menganalisa sistem yang akan dikembangkan.

Untuk mendapatkan gambaran mengenai sistem baru yang diusulkan serta memperjelas ruang lingkup penulisan maka perlu dijabarkan context diagram pada Gambar 3.5.

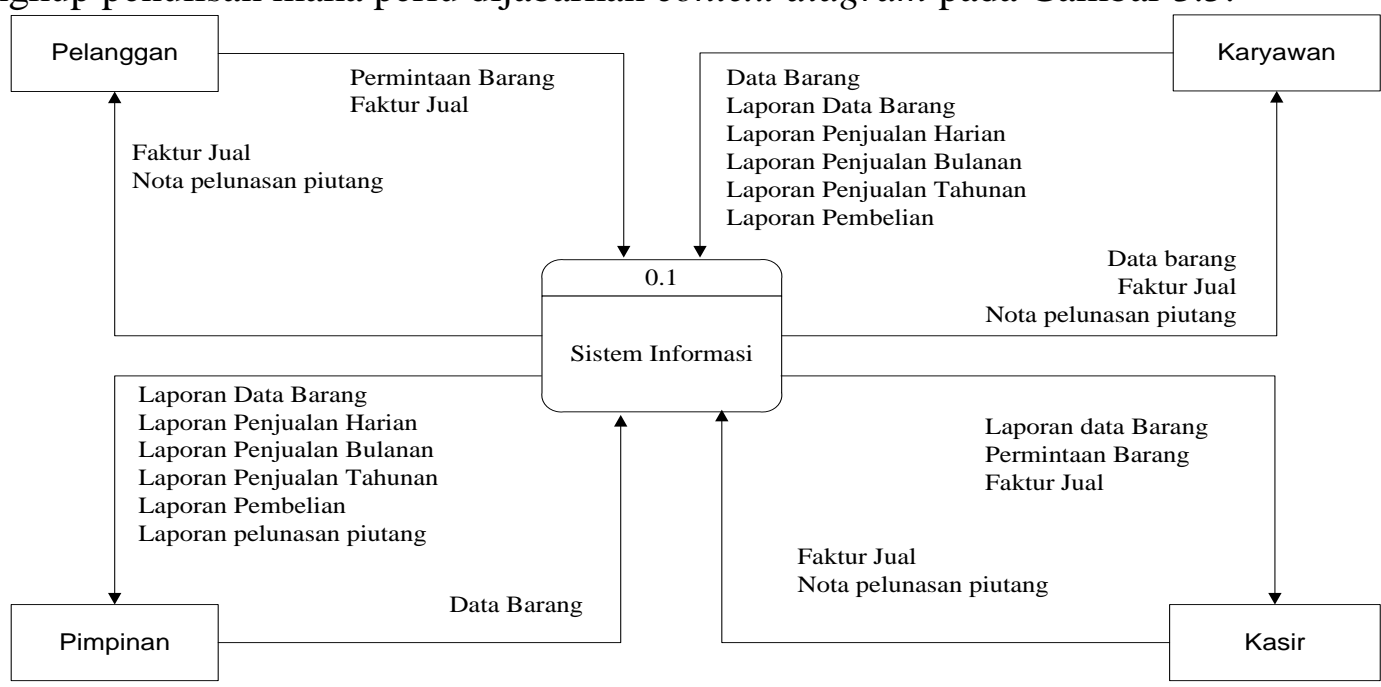

\section{Gambar 3.5 Context Diagram Sistem Informasi}

\subsection{Data Flow Diagram Level 0}

Data Flow Diagram level 0 merupakan penjabaran dari context diagram seperti dapat dilihat pada Gambar 3.6 berikut:

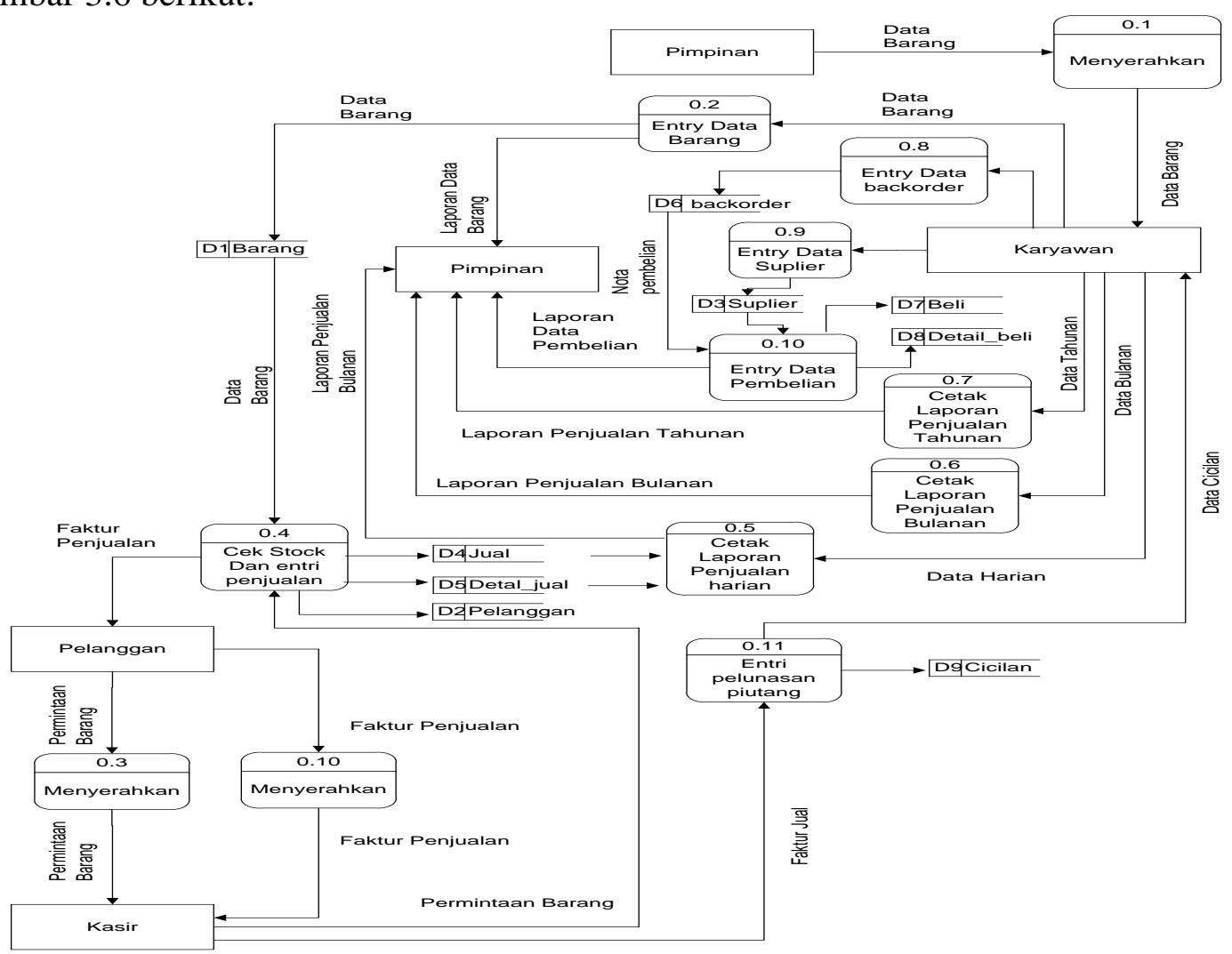

Gambar 3.6 Data Flow Diagram Level 0 


\subsection{ERD ( Entity Relationship Diagram )}

Entity Relationship Diagram Merupakan diagram yang menggambarkan hubungan antara entity dalam sebuah database. Pada diagram ini dapat dilihat hubungan antar file dalam sistem informasi persediaan Toko Master. Untuk lebih jelasnya ERD Sistem informasi penjualan dapat digambarkan seperti Gambar 3.7.

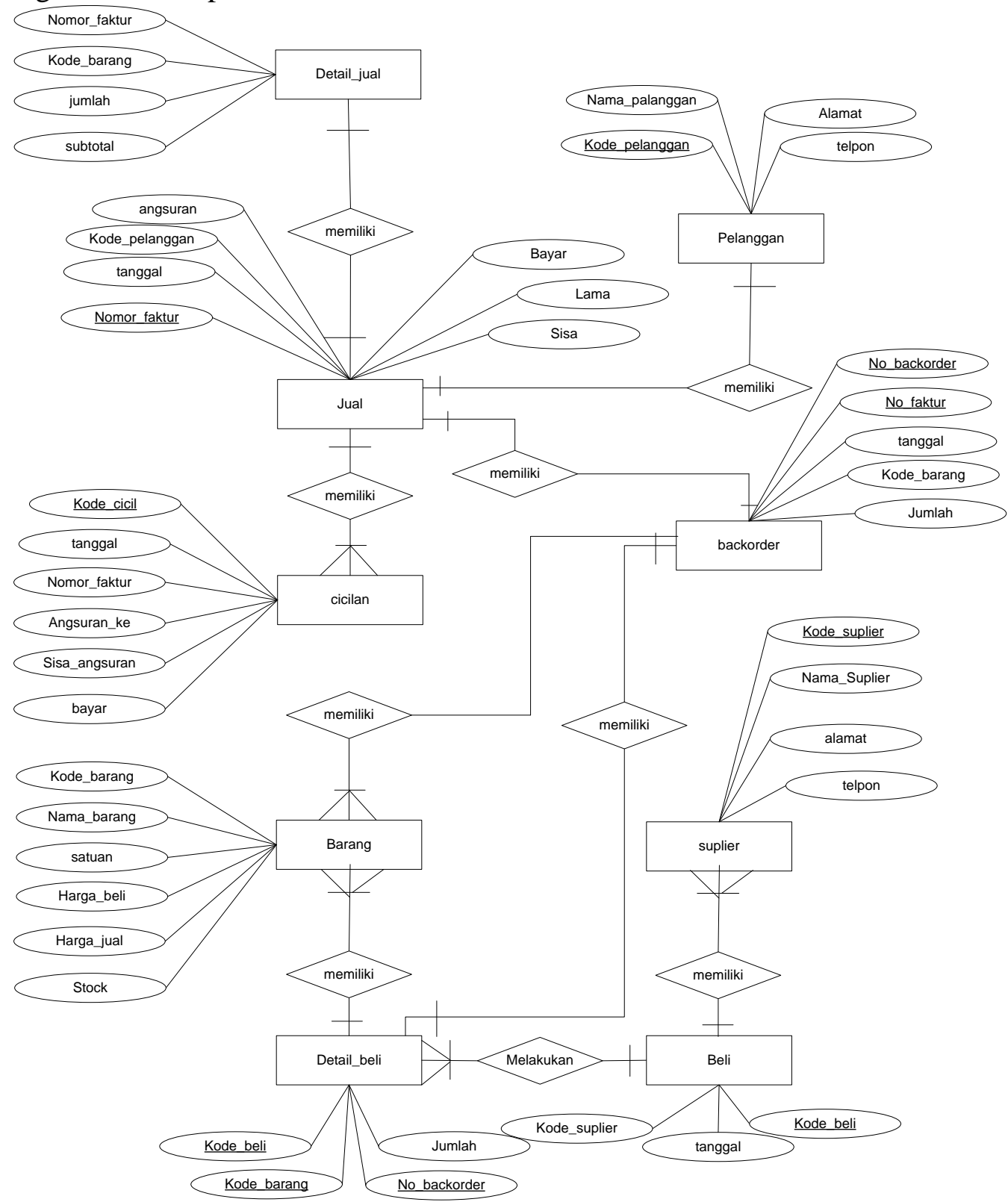

Gambar 3.7 Entity Relathionship Diagram (ERD)

\subsection{Pengujian Sistem}

Pada bagian pengujian program ini akan dijelaskan mengenai penggunaan dari aplikasi yang dibuat. Penjelasan aplikasi yang dibuat meliputi tampilan aplikasi, fungsi kontrol dalam aplikasi, serta cara penggunaanya. Pada sub bab akan dijelaskan tentang penggunaan aplikasi per sistem menu, mulai dari tampilan menu utama, fungsi dan cara penggunaannya sampai selesai. 


\section{Tampilan Form Login}

Disini terlihat form login yang digunakan untuk keamanan sistem, untuk dapat masuk ke sistem informasi pengolahan stock pada Toko Master kita harus mengentrikan username dan password. seperti gambar 4.9.

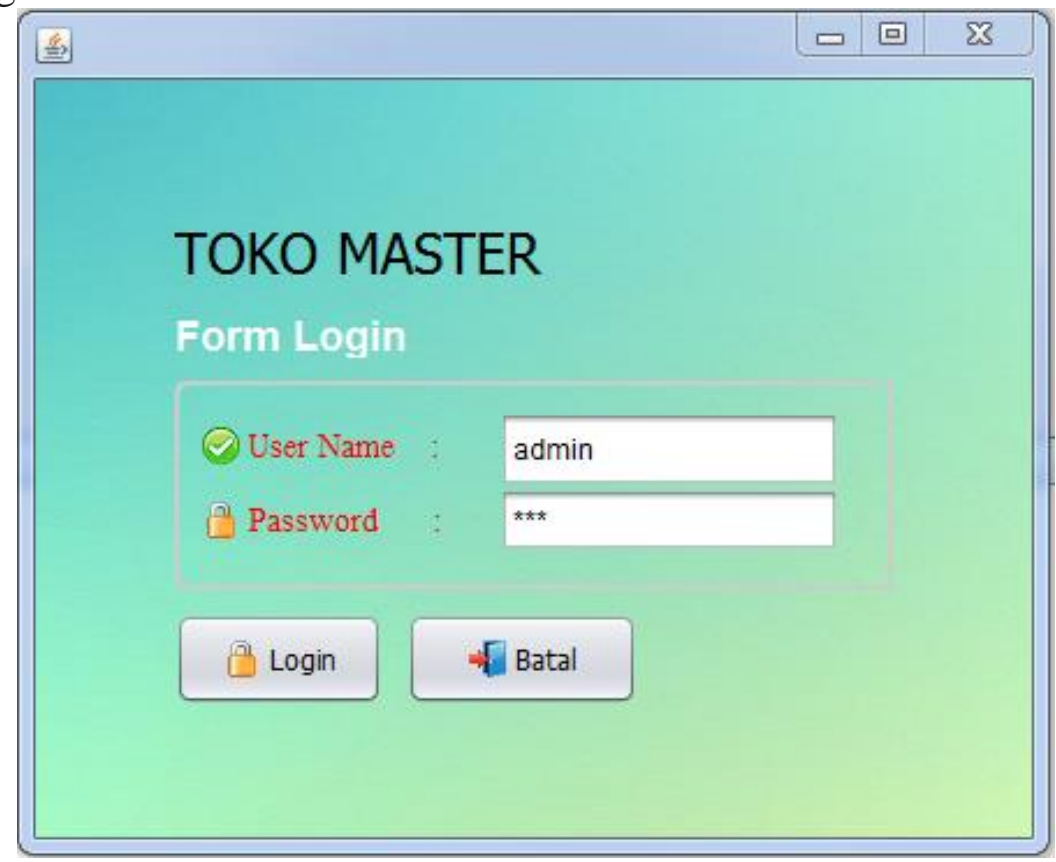

Gambar 4.9. Form Login

\section{Tampilan Menu Utama}

Disini terlihat beberapa menu pada Menu utama yaitu menu Entry, Laporan, Transaksi dan Exit. seperti gambar 4.10.

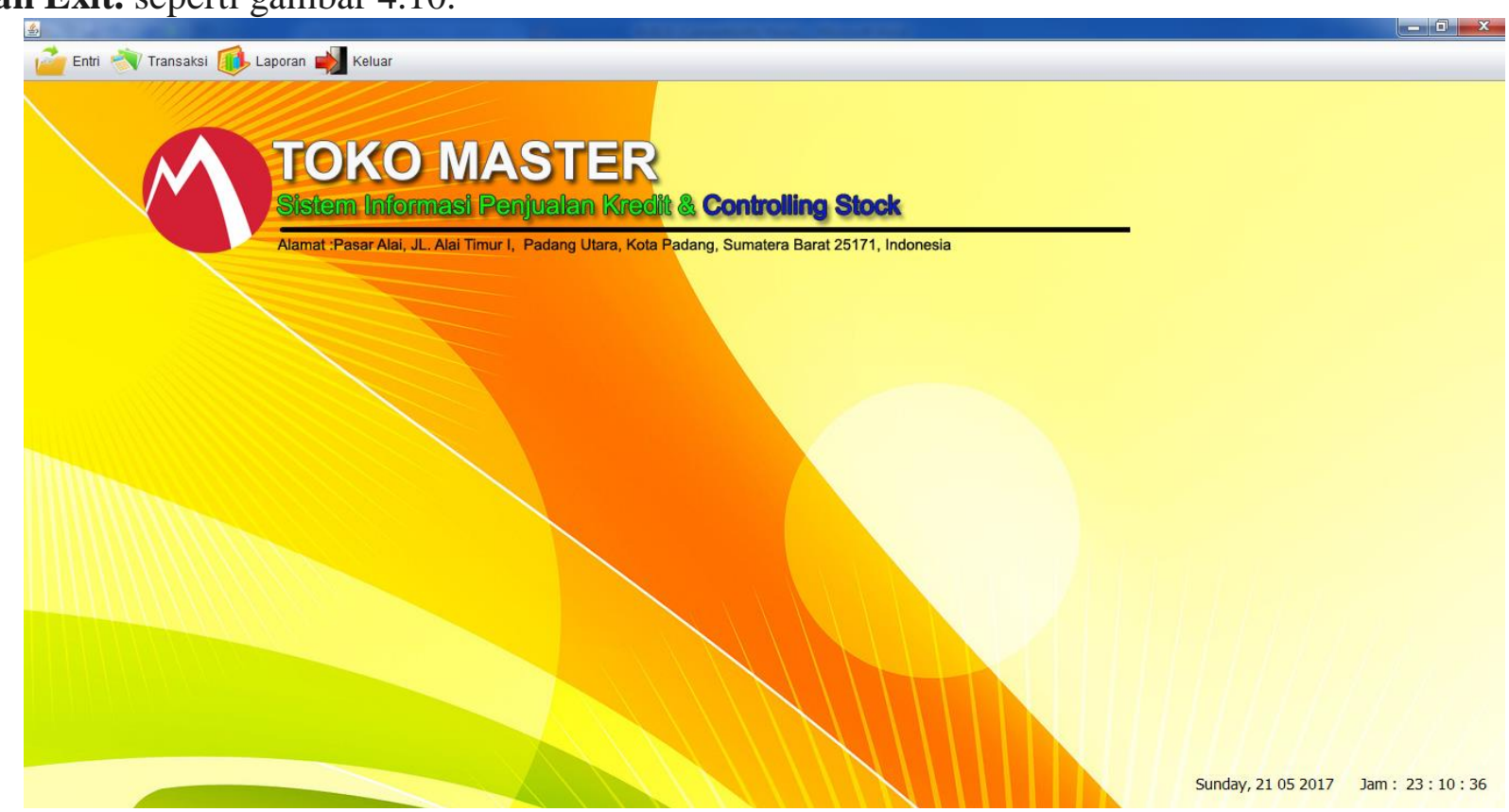

\section{Entry Barang}

\section{Gambar 4.10. Menu Utama}

Form Ini berguna untuk mendata seluruh barang. Terdapat tombol Simpan/Ubah, berguna dalam menyimpan data ke database dan memperbaharui data dalam database, serta tombol keluar untuk keluar. Untuk menginputkan data Barang klik Entry pada menu, pilih Barang, dan isi data Barang seperti gambar 4.11. 


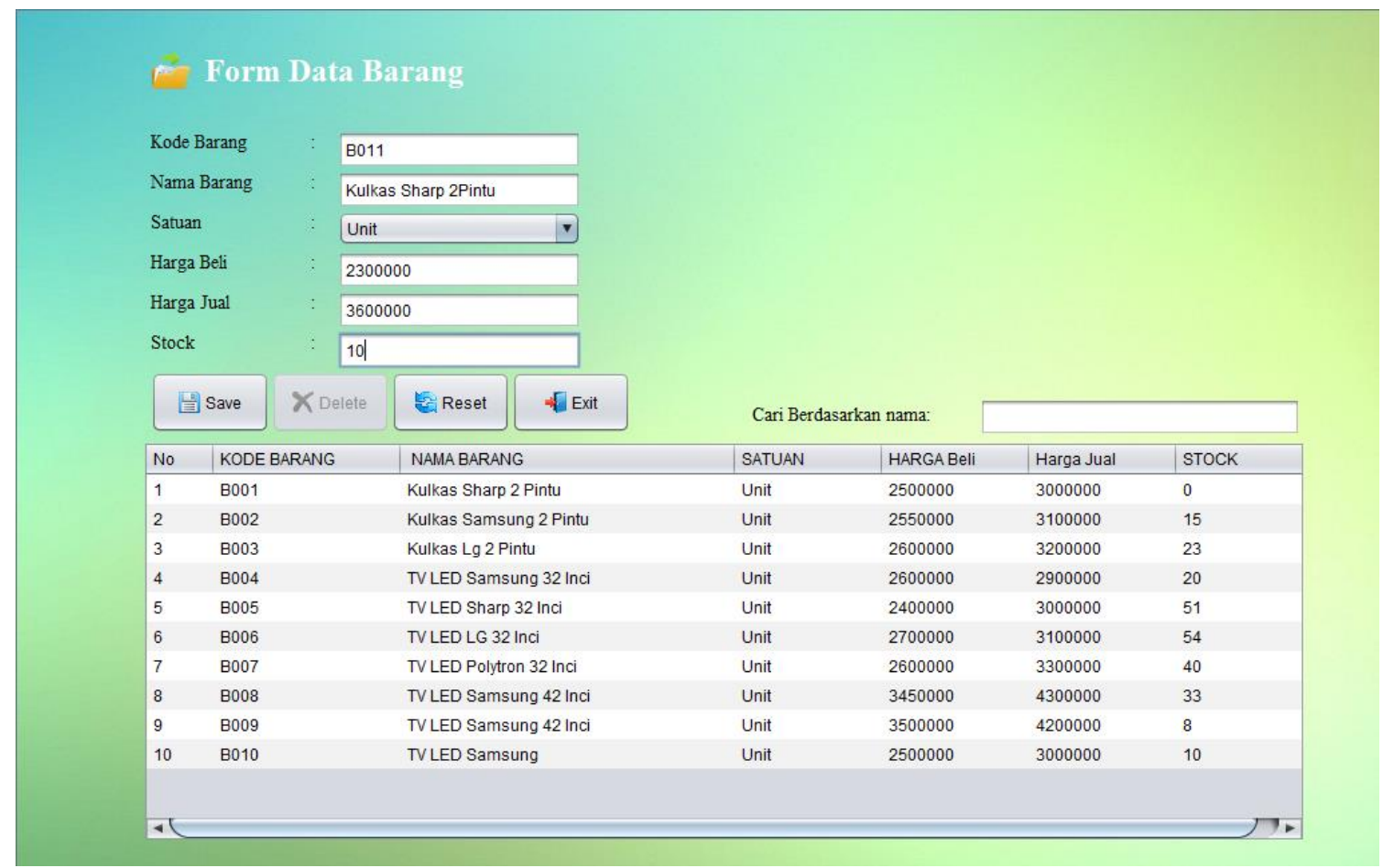

\section{Entry Pelanggan}

\section{Gambar 4.11. Entry Data Barang}

Form Ini berguna untuk mendata seluruh pelanggan. Terdapat tombol Simpan/Ubah, berguna dalam menyimpan data ke database dan memperbaharui data dalam database, serta tombol keluar untuk keluar. Untuk menginputkan data Pelanggan klik Entry pada menu, pilih Pelanggan, dan isi data Pelanggan seperti gambar 4.12.

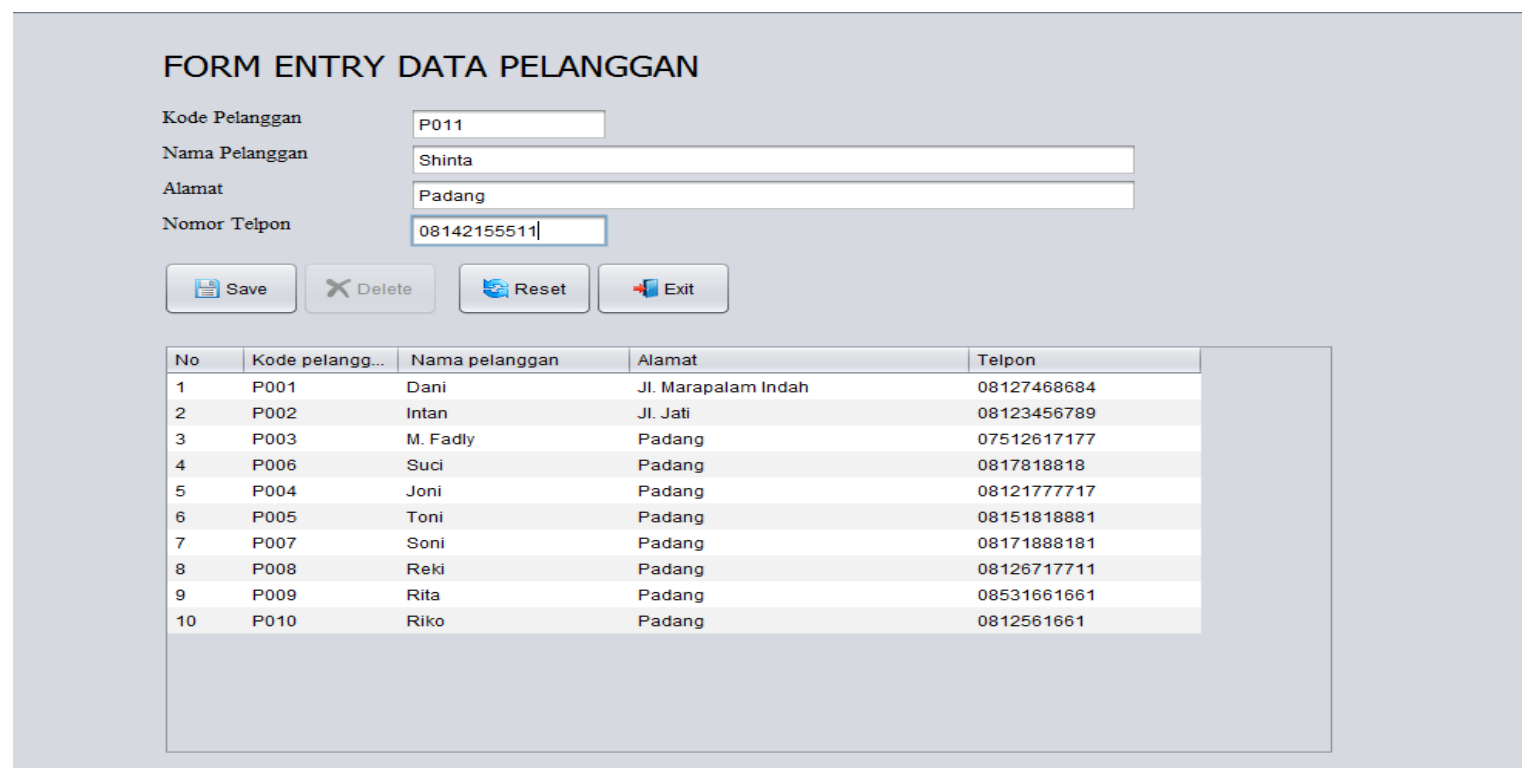

\section{Gambar 4.12. Entry Data Pelanggan}

\section{Entry Suplier}

Form Ini berguna untuk mendata seluruh suplier. Terdapat tombol Simpan/Ubah, berguna dalam menyimpan data ke database dan memperbaharui data dalam database, serta tombol keluar untuk keluar. Untuk menginputkan data Suplier klik Entry pada menu, pilih Suplier, dan isi data Suplier seperti gambar 4.13. 


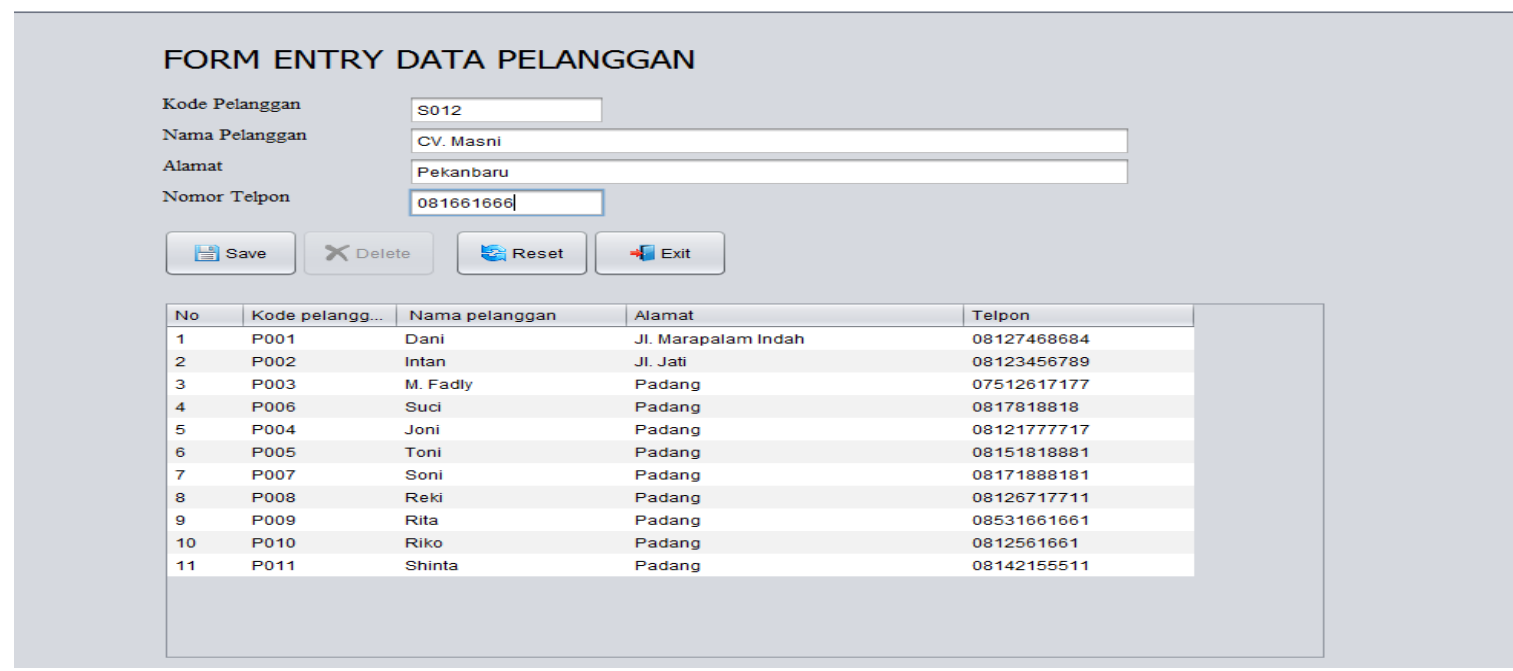

\section{Entry Penjualan}

\section{Gambar 4.13. Entry Data Suplier}

Form Ini berguna untuk mendata seluruh penjualan. Terdapat tombol Simpan/Ubah, berguna dalam menyimpan data ke database dan memperbaharui data dalam database, serta tombol keluar untuk keluar seperti gambar 4.14.

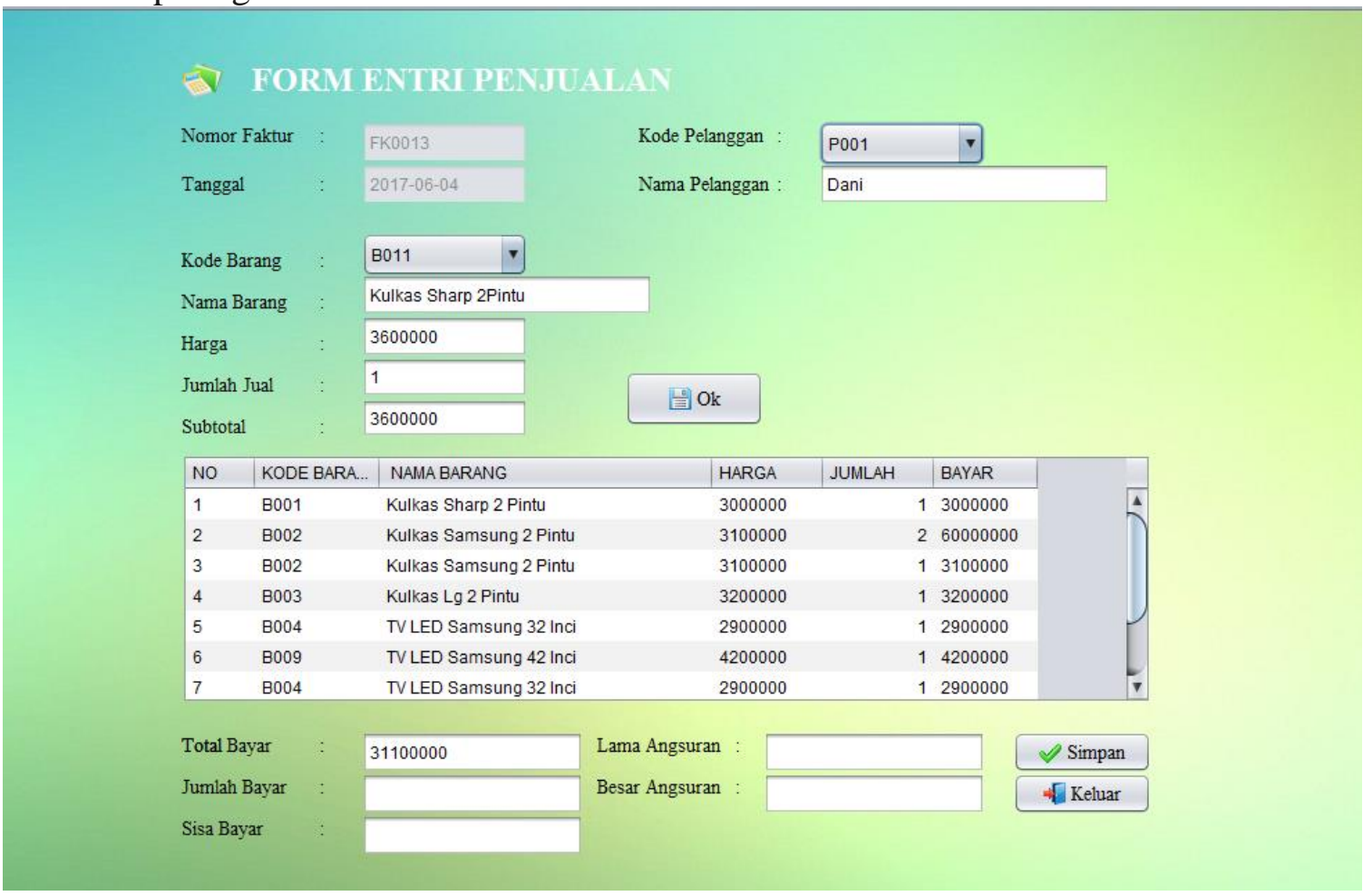

Gambar 4.14. Entry Data Penjualan

\section{Entry Cicilan}

Form Ini berguna untuk mendata seluruh cicilan. Terdapat tombol Simpan/Ubah, berguna dalam menyimpan data ke database dan memperbaharui data dalam database, serta tombol keluar untuk keluar seperti gambar 4.15. 


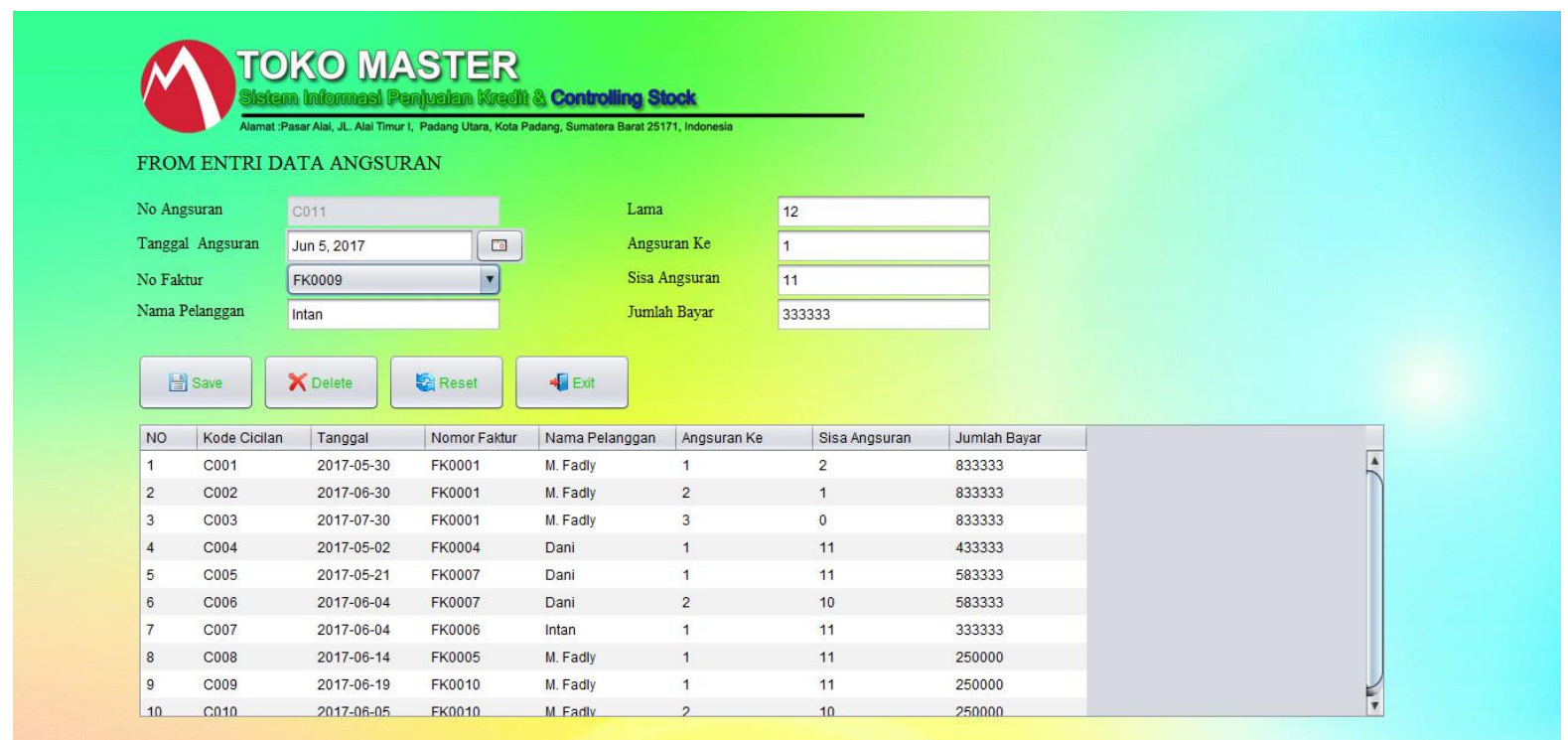

\section{Gambar 4.15. Entry Data Cicilan}

\section{Entry Pembelian}

Form Ini berguna untuk mendata seluruh pembelian. Terdapat tombol Simpan/Ubah, berguna dalam menyimpan data ke database dan memperbaharui data dalam database, serta tombol keluar untuk keluar. seperti gambar 4.16.

- FORM DNIRI PEMRBEIAN

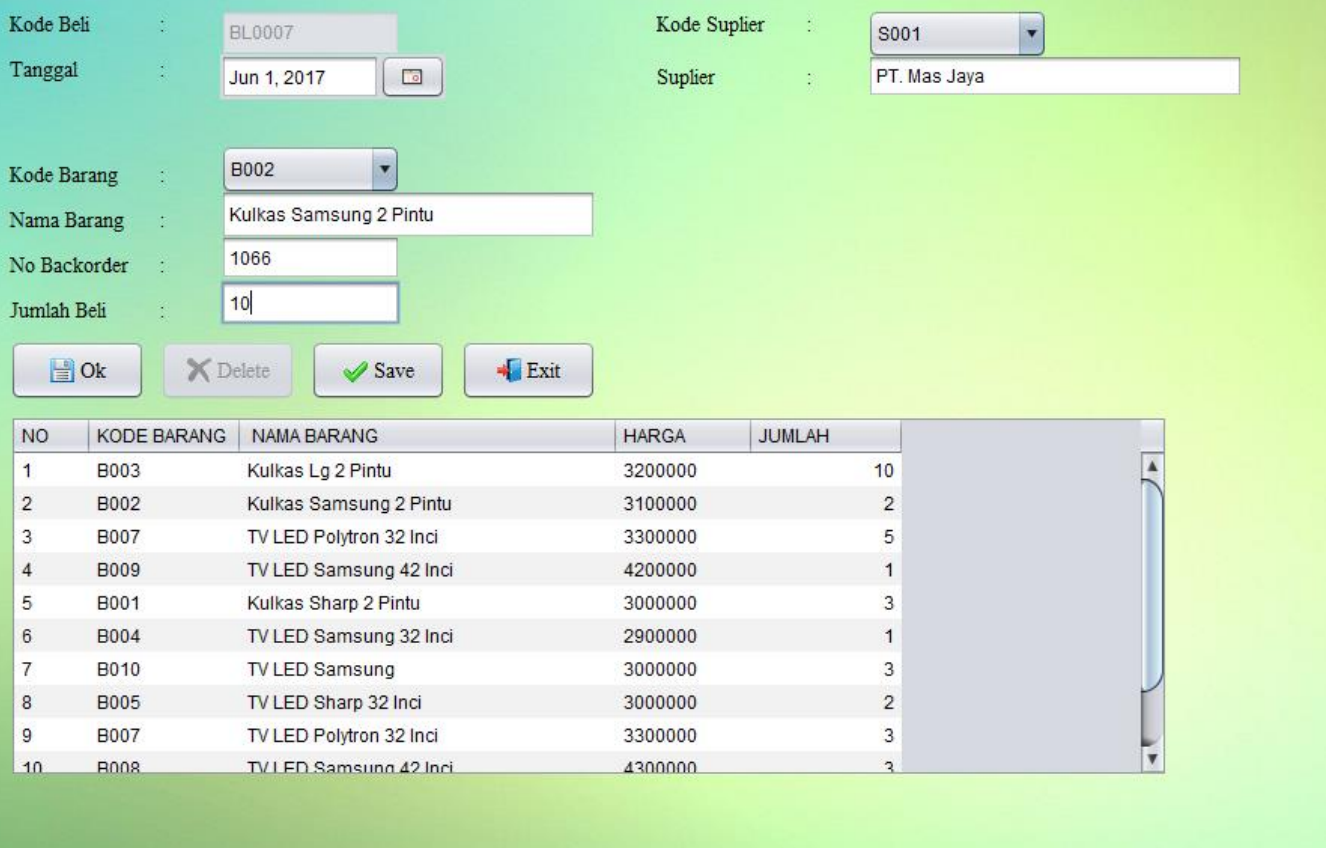

\section{Gambar 4.16. Entry Data Pembelian}

\section{Entry Backorder}

Form Ini berguna untuk mendata seluruh Backorder. Terdapat tombol Simpan/Ubah, berguna dalam menyimpan data ke database dan memperbaharui data dalam database, serta tombol keluar untuk keluar. seperti gambar 4.17. 
T FORM BACKORDER

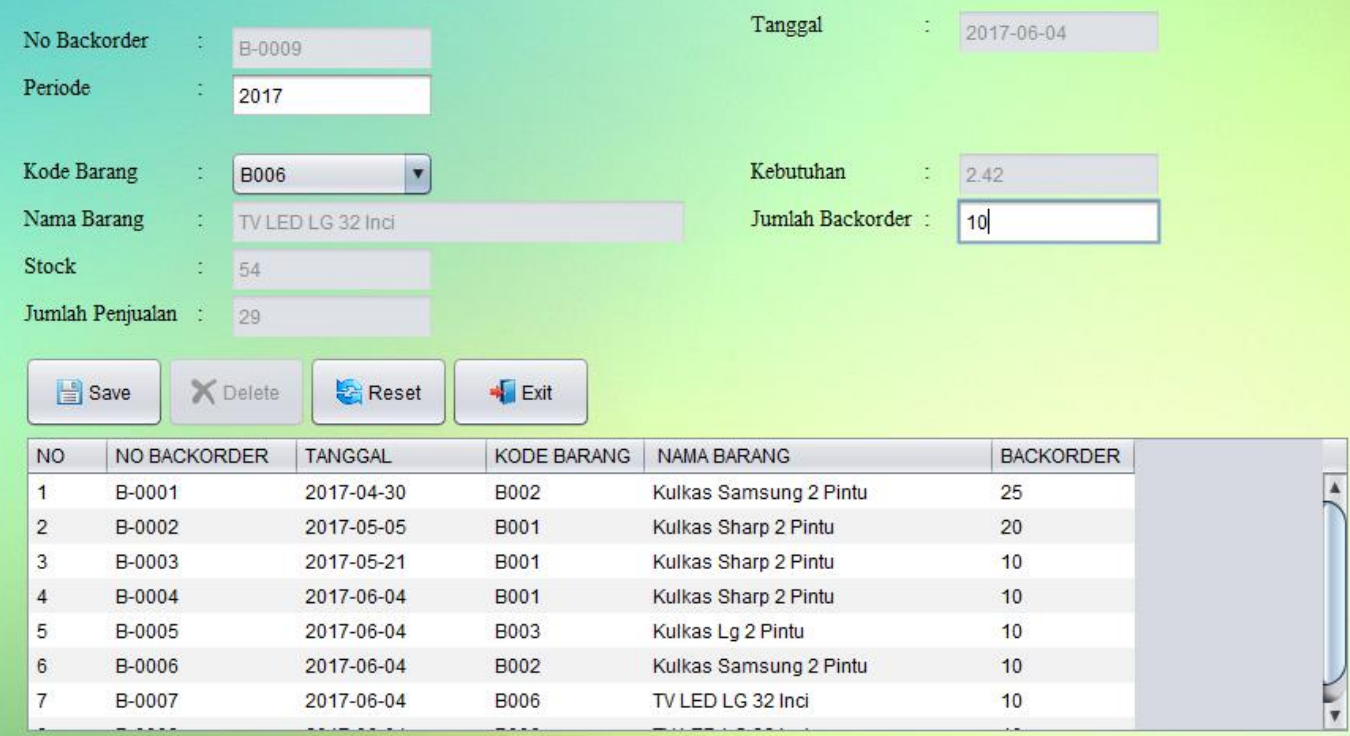

\section{Gambar 4.17. Entry Data Backorder}

\section{Bentuk Faktur Jual}

Untuk menampilkan dan mencetak Faktur Jual maka dapat dilakukan dengan cara klik menu Laporan dan kemudian pilih Faktur Jaul lalu kita diminta untuk pilih nomor faktur kemudian akan tampil faktur jual seperti gambar 4.18.

\section{TOKO MASTER}

Alamat :Pasar Alai, JL. Alai Timur I, Padang Utara, Kota Padang. Sumatera Barat 25171, Indonesia

\begin{tabular}{|c|c|c|c|c|c|}
\hline \multicolumn{6}{|c|}{ FAKTUR JUAL } \\
\hline \multicolumn{2}{|c|}{ Nomor Faktur } & : FKO013 & Pelanggan & \multicolumn{2}{|l|}{ : Dani } \\
\hline \multicolumn{2}{|l|}{ Tanggal } & : 04/06/2017 & Alamat & \multicolumn{2}{|c|}{ : Jl. Marapalam Indah } \\
\hline \multicolumn{2}{|c|}{ Sisa Bayar } & : 30100000 & & & \\
\hline NO & KODE & NAMA BARANG & HARGA & JUMLAH & SUB TOTAL \\
\hline 1 & Boo1 & Kulkas Sharp 2 Pintu & $3,000,000$ & 1 & $3,000,000$ \\
\hline 2 & BOO2 & Kulkas Samsung 2 Pintu & $3,100,000$ & 2 & $60,000,000$ \\
\hline 3 & BO02 & Kulkas Samsung 2 Pintu & $3,100,000$ & 1 & $3,100,000$ \\
\hline 4 & во03 & Kulkas Lg 2 Pintu & $3,200,000$ & 1 & $3,200,000$ \\
\hline 5 & BO04 & TV LED Samsung 32 Inci & $2,900,000$ & 1 & $2,900,000$ \\
\hline 6 & Boog & TV LED Samsung 42 Inci & $4,200,000$ & 1 & $4,200,000$ \\
\hline 7 & BOO4 & TV LED Samsung 32 Inci & $2,900,000$ & 1 & $2,900,000$ \\
\hline 8 & во08 & TV LED Samsung 42 Inci & $4,300,000$ & 1 & $4,300,000$ \\
\hline 9 & Boog & TV LED Samsung 42 Inci & $4,200,000$ & 1 & $4,200,000$ \\
\hline 10 & Boo7 & TV LED Polytron 32 Inci & $3,300,000$ & 1 & $3,300,000$ \\
\hline \multicolumn{5}{|c|}{ TOTAL } & $91,100,000$ \\
\hline
\end{tabular}

Gambar 4.18. Faktur Jual

Toko Master 


\section{Bentuk Laporan Persediaan Barang}

Untuk menampilkan dan mencetak Laporan Data Persediaan Barang maka dapat dilakukan dengan cara klik menu Laporan dan kemudian pilih Laporan Persediaan Barang lalu kita diminta untuk menginputkan nama Pimpinan kemudian akan tampil laporan persediaan barang seperti gambar 4.19 .

TOKO MASTER

Alamat :Pasar Alai, JL. Alai Timur I, Padang Utara, Kota Padang. Sumatera Barat 25171, Indonesia

\begin{tabular}{|c|c|c|c|c|c|}
\hline \multicolumn{6}{|c|}{ LAPORAN DATA PERSEDIAAN BARANG } \\
\hline NO & KODE & NAMA BARANG & SATUAN & HARGA & STOCK \\
\hline 1 & Boo1 & Kulkas Sharp 2 Pintu & Unit & $3,000,000$ & 9 \\
\hline 2 & $\mathrm{BO} 2$ & Kulkas Samsung 2 Pintu & Unit & $3,100,000$ & 14 \\
\hline 3 & вооз & Kulkas Lg 2 Pintu & Unit & $3,200,000$ & 22 \\
\hline 4 & BO०4 & TV LED Samsung $32 \mathrm{lnci}$ & Unit & $2,900,000$ & 18 \\
\hline 5 & Boog & TV LED Samsung 42 Inci & Unit & $4,200,000$ & 6 \\
\hline 6 & воов & TV LED Samsung 42 inci & Unit & $4,300,000$ & 32 \\
\hline 7 & Boo7 & TV LED Polytron 32 Inci & Unit & $3,300,000$ & 39 \\
\hline 8 & во06 & TV LED LG 32 Inci & Unit & $3,100,000$ & 54 \\
\hline 9 & Boo5 & TV LED Sharp 32 Inci & Unit & $3,000,000$ & 51 \\
\hline 10 & Bo10 & TV LED Samsung & Unit & $3,000,000$ & 10 \\
\hline 11 & B011 & Kulkas Sharp 2Pintu & Unit & $3,600,000$ & 10 \\
\hline
\end{tabular}

\section{Gambar 4.19. Laporan Data Persediaan Barang}

\section{Bentuk Laporan Penjualan Harian}

Untuk menampilkan dan mencetak Laporan Penjualan Harian maka dapat dilakukan dengan cara klik menu Laporan dan kemudian pilih Laporan Penjualan Harian lalu kita diminta untuk menginputkan nama Pimpinan dan Tanggal maka akan muncul laporan penjualan harian seperti gambar 4.20 .

TOKO MASTER

Alamat :Pasar Alai, JL. Alai Timur I, Padang Utara, Kota Padang. Sumatera Barat 25171, Indonesia Laporan Penjualan Harian Tanggal :04/06/2017

\begin{tabular}{|c|c|c|c|c|c|c|}
\hline No & FAKTUR & PELANGGAN & BARANG & HARGA & JUMLAH & SUB TOTAL \\
\hline 1 & FKO013 & Dani & Kulkas Sharp 2 Pintu & $3,000,000$ & 1 & $3,000,000$ \\
\hline 2 & FKOO 13 & Dani & Kulkas Samsung 2 Pintu & $3,100,000$ & 2 & $60,000,000$ \\
\hline 3 & FKOO 13 & Dani & Kulkas Samsung 2 Pintu & $3,100,000$ & 1 & $3,100,000$ \\
\hline 4 & FKOO 13 & Dani & Kulkas Lg 2 Pintu & $3,200,000$ & 1 & $3,200,000$ \\
\hline 5 & FKOO 13 & Dani & TV LED Samsung 32 inci & $2,900,000$ & 1 & $2,900,000$ \\
\hline 6 & FKO013 & Dani & TV LED Samsung 42 Inci & $4,200,000$ & 1 & $4,200,000$ \\
\hline 7 & FKOO 13 & Dani & TV LED Samsung 32 Inci & $2,900,000$ & 1 & $2,900,000$ \\
\hline 8 & FKO0 13 & Dani & TV LED Samsung 42 Inci & $4,300,000$ & 1 & $4,300,000$ \\
\hline 9 & FKOO13 & Dani & TV LED Samsung 42 Inci & $4,200,000$ & 1 & $4,200,000$ \\
\hline 10 & FKO013 & Dani & TV LED Polytron 32 Inci & $3,300,000$ & 1 & $3,300,000$ \\
\hline \multicolumn{6}{|c|}{ TOTAL } & $91,100,000$ \\
\hline
\end{tabular}

Gambar 4.20. Laporan Penjulan Harian 


\section{Bentuk Laporan Penjualan Bulanan}

Untuk menampilkan dan mencetak Laporan Penjualan Bulanan maka dapat dilakukan dengan cara klik menu Laporan dan kemudian pilih Laporan Penjualan Bulanan lalu kita diminta untuk menginputkan nama Pimpinan dan Bulanan maka akan muncul laporan penjualan bulanan seperti gambar 4.21.

TOKO MASTER

Alamat :Pasar Alai, JL. Alai Timur I, Padang Utara, Kota Padang, Sumatera Barat 25171, Indonesia

\begin{tabular}{|c|c|c|c|c|c|c|c|}
\hline \multicolumn{8}{|c|}{$\begin{array}{l}\text { Laporan Penjualan Bulanan } \\
\qquad \text { Bulan :Jun-2017 }\end{array}$} \\
\hline NO & FAKTUR & TANGGAL & PELANGGAN & BARANG & HARGA & JUMLAH & SUB TOTAL \\
\hline 1 & FKooos & $09 / 06 / 2017$ & Intan & Kulkas Lg 2 Pintu & $3,200,000$ & 28 & $64,000,000$ \\
\hline 2 & FKOO13 & $04 / 06 / 2017$ & Dani & Kulkas Sharp 2 Pintu & $3,000,000$ & 1 & $3,000,000$ \\
\hline 3 & FKO0 13 & $04 / 06 / 2017$ & Dani & Kulkas Samsung 2 Pintu & $3,100,000$ & 2 & $60,000,000$ \\
\hline 4 & FKO013 & $04 / 06 / 2017$ & Dani & Kulkas Samsung 2 Pintu & $3,100,000$ & 1 & $3,100,000$ \\
\hline 5 & FKOO 13 & $04 / 06 / 2017$ & Dani & Kulkas Lg 2 Pintu & $3,200,000$ & 1 & $3,200,000$ \\
\hline 6 & FKOO13 & $04 / 06 / 2017$ & Dani & TV LED Samsung 32 Inci & $2,900,000$ & 1 & $2,900,000$ \\
\hline 7 & FKO013 & $04 / 06 / 2017$ & Dani & TV LED Samsung 42 Inci & $4,200,000$ & 1 & $4,200,000$ \\
\hline 8 & FKOO 13 & $04 / 06 / 2017$ & Dani & TV LED Samsung 32 Inci & $2,900,000$ & 1 & $2,900,000$ \\
\hline 9 & FKOO13 & $04 / 06 / 2017$ & Dani & TV LED Samsung 42 Inci & $4,300,000$ & 1 & $4,300,000$ \\
\hline 10 & FKOO13 & $04 / 06 / 2017$ & Dani & TV LED Samsung 42 Inci & $4,200,000$ & 1 & $4,200,000$ \\
\hline 11 & FKOO 13 & $04 / 06 / 2017$ & Dani & TV LED Polytron 32 Inci & $3,300,000$ & 1 & $3,300,000$ \\
\hline \multicolumn{7}{|c|}{ TOTAL } & $155,100,000$ \\
\hline
\end{tabular}

\section{Gambar 4.21. Laporan Penjulan Bulanan}

\section{Bentuk Laporan Penjualan Tahunan}

Untuk menampilkan dan mencetak Laporan Penjualan Tahunan maka dapat dilakukan dengan cara klik menu Laporan dan kemudian pilih Laporan Penjualan Tahunan lalu kita diminta untuk menginputkan nama Pimpinan dan Tahun maka akan muncul laporan penjualan Tahunan seperti gambar 4.22.

TOKO MASTER

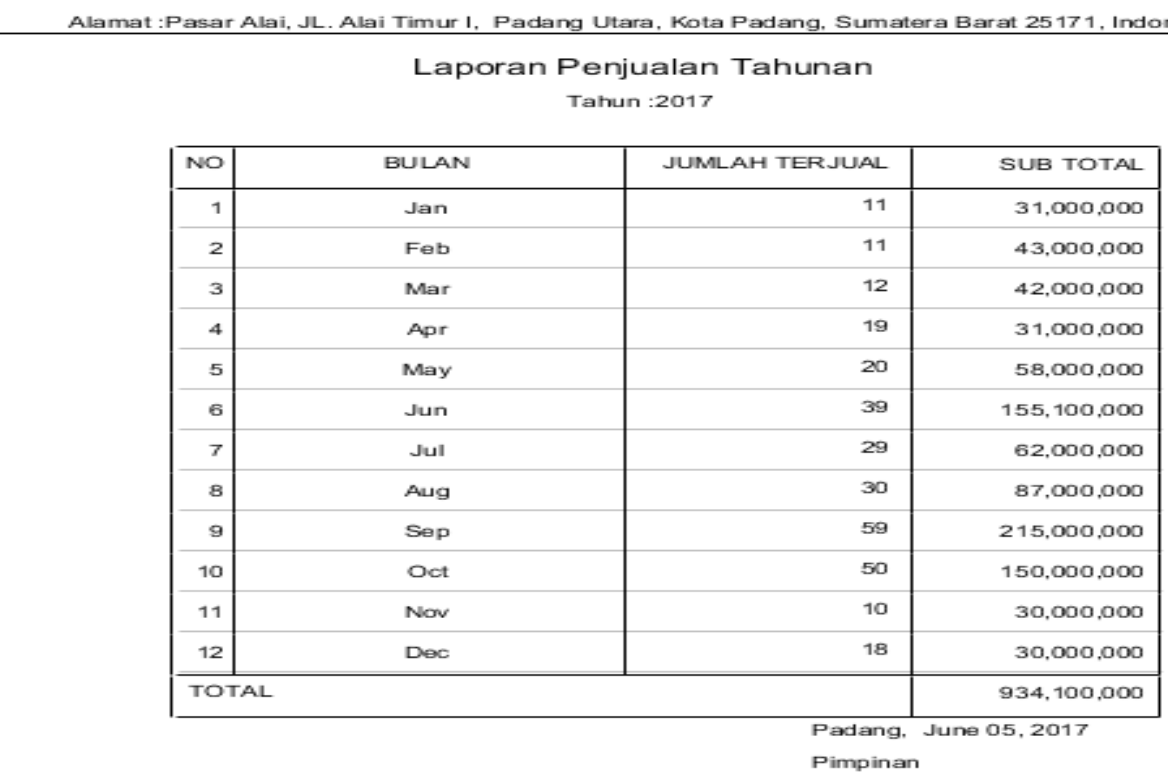

Gambar 4.22. Laporan Penjulan Tahunan 


\section{Bentuk Laporan Pembelian}

Untuk menampilkan dan mencetak Laporan Pembelian maka dapat dilakukan dengan cara klik menu Laporan dan kemudian pilih Laporan Pembelian lalu kita diminta untuk menginputkan nama Pimpinan dan Tahun maka akan muncul laporan Pembelian seperti gambar 4.23 .

TOKO MASTER

\begin{tabular}{|c|c|c|c|c|}
\hline \multicolumn{5}{|c|}{$\begin{array}{l}\text { Laporan Pembelian } \\
\text { Bulan :Jun-2017 }\end{array}$} \\
\hline No & KODE BELI & KODE BARANG & NAMA BARANG & JUMLAH BELI \\
\hline 1 & BLO007 & BO03 & Kulkas Lg 2 Pintu & 10 \\
\hline 2 & BLOoO7 & BOO2 & Kulkas Samsung 2 Pintu & 2 \\
\hline 3 & BLOo07 & Boo7 & TV LED Polytron 32 Inci & 5 \\
\hline 4 & BLooo7 & Boog & TV LED Samsung 42 inci & 1 \\
\hline 5 & BLooor & Boo1 & Kulkas Sharp 2 Pintu & 3 \\
\hline 6 & BLooor & BOO4 & TV LED Samsung 32 Inci & 1 \\
\hline 7 & BLooor & B010 & TV LED Samsung & 3 \\
\hline 8 & BLOo07 & Boo5 & TV LED Sharp 32 Inci & 2 \\
\hline 9 & BLooor & Boo7 & TV LED Polytron 32 Inci & 3 \\
\hline 10 & BLooo7 & Bо08 & TV LED Samsung $42 \mathrm{Inci}$ & 3 \\
\hline 11 & BLOo07 & BO04 & TV LED Samsung 32 Inci & 1 \\
\hline 12 & BLooor & Boo1 & Kulkas Sharp 2 Pintu & 10 \\
\hline \multicolumn{5}{|c|}{$\begin{array}{l}\text { Padang. June 05, } 2017 \\
\text { Pimpinan }\end{array}$} \\
\hline
\end{tabular}

\section{Gambar 4.23. Laporan Pembelian}

\section{Bentuk Grafik Penjualan}

Untuk menampilkan dan mencetak Grafik Penjualan maka dapat dilakukan dengan cara klik menu Laporan dan kemudian pilih Grafik Penjualan lalu kita diminta untuk menginputkan nama Pimpinan dan Tahun maka akan muncul laporan Grafik Penjualan seperti gambar 4.24.

\section{TOKO MASTER}

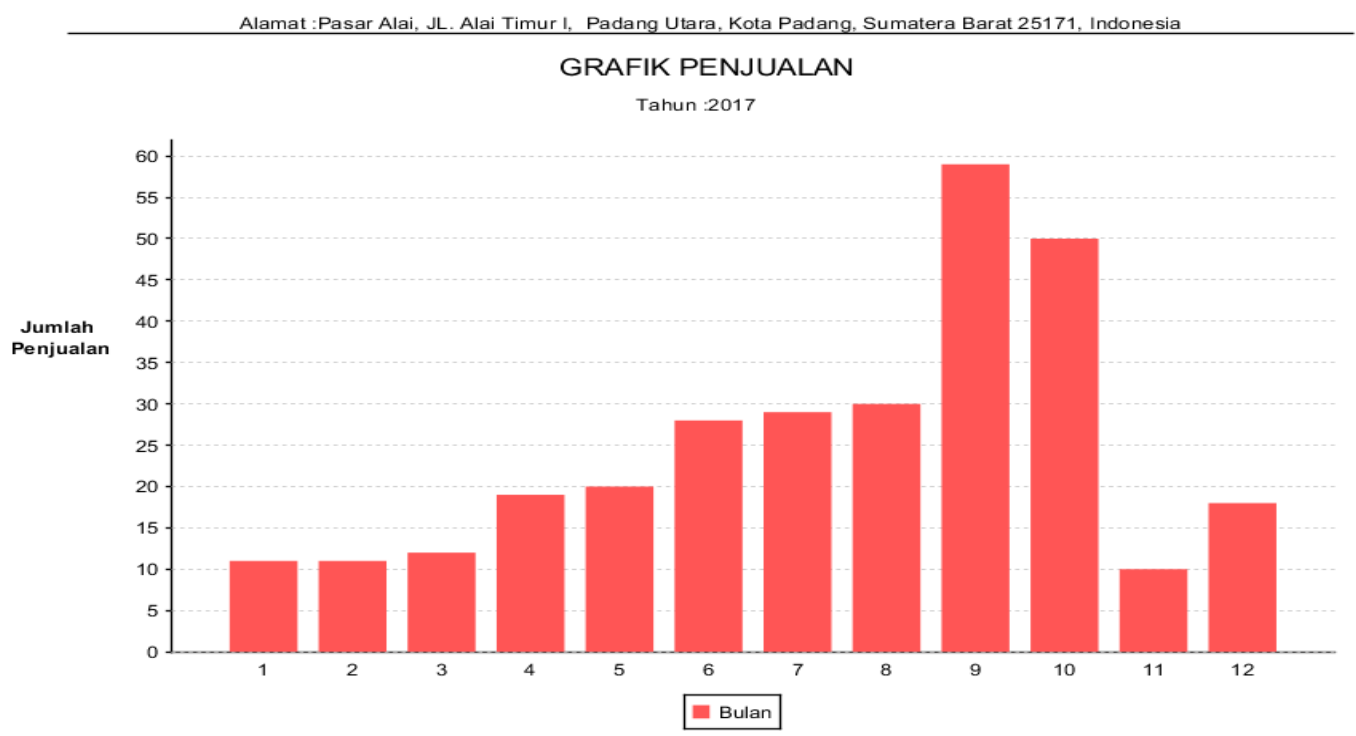

Gambar 4.24. Laporan Grafik Penjualan 
Pada grafik diatas adalah laporan jumlah barang terjual dalam tahun 2017 yaitu terdiri dari 12 bulan mulai januari sampai desember. Bulan januari jumlah penjualan berjumlah 10, februari 10, maret 11, april 19 , mei 20, juni 28, juli 29, agustus 30, September 58, oktober 20, November 10 dan desember sebanyak 18 barang yang terjual.

\section{Kesimpulan}

Berdasarkan perancangan sistem informasi penjualan dan pengolahan stock barang serta analisa-analisa yang dilakukan pada Toko Master, maka penulis mengambil beberapa kesimpulan, yaitu:

1. Dengan desain sistem baru secara komputerisasi dan mengaplikasikan kedalam Bahasa Pemograman Java dalam perancangan sistem informasi penjualan kredit dan pengendalian stok barang dengan menerapkan metode Backorder dapat membantu perusahaan dalam menyajikan informasi yang akurat dan efisien.

2. Dengan desain sistem baru diharapkan informasi tersebut dapat disimpan dengan menyediakan file-file dalam database, maka informasi tersebut sewaktu-waktu dapat di update dengan tepat.

3. Dengan menggunakan sistem informasi penjualan kredit dan pengendalian stok barang dapat mengetahui stok akhir barang untuk melakukan order barang..

4. Sistem stock barang yang baru menggunakan bahasa pemrograman Java, dimana pemakai sistem tidak perlu memikirkan biaya lisensi dari aplikasi tersebut karena bahasa pemrograman tersebut gratis dalam pemakaiannya.

\section{Referensi}

A.S, Rosa, Shalahuddin, M. 2013. Rekayasa Perangkat Lunak. Bandung: Informatika bandung.

Anwar, Nurul Fitah. 2014. Analisis Penerapan Metode Pencatatan dan Penilaian Terhadap Persediaan Barang Menurut PSAK No. 14 Pada PT. Tirta Investama DC Manad. Vol.2 No.2. Jurnal Emba

Budiati, Lina. 2016. Model Deteministik Eoq dengan Backorder Parsial. No. 1 Vol. 1 Junal Emba

Cahyana, Nur Heri. 2014. Sistem Informasi Persediaan Barang Berbasis Web di PT. Agung. Vol.2 No.2 Juni 2014. Jurnal Emba

F. Anwar, Nurul dan Karamoy (2014). Analisis Penerapan Metode Pencatatan dan Penilaian Terhadap Persediaan Barang Menurut PSAK No. 14 Pada PT Tirta Investama DC Manado. Vol.2 No.2. Jurnal Emba.

Frasa, Citra Aulia Hani. 2012. Manajemen Persediaan Produk Ikan Segar Ritel Moderen . Vol 3. No. 3. Jurnal Emba

Kadir, Abdul. 2013. Pengenalan Sistem Informasi. Yogyakarta :Andi

Machmud, Pinati Sherly. 2014. Peran Controller Dalam Usaha Meminimalisasi Resiko Kehilangan Persediaan Barang Dagangan Pada Jumbo Swaalyan Manado. Vol. 2 No. 2 jurnal emba 
Machmud, Rizal. 2013. peranan penerapan sistem informasi manajemen terhadap efektivitas kerja pagawai lembaga pemasyarakatan narkotika (lapastika) bollangi kabupaten gowa. Vol.9 No.3. Jurnal Emba

Makisurat, Aprilia, Morasa, dan Elim (2014). Penerapan Sistem Pengendalian Intern Untuk Persediaan Barang Dagangan Pada CV. Multi Media Persada Manado. Vol.2 No.2 Jurnal Emba.

Nugrahanti, Fati. 2015. PERANCANGAN SISTEM INFORMASI INVENTORY SPAREPART MESIN FOTOCOPY DENGAN MENGGUNAKAN VISUAL DELPHI 7 (Studi KasUs di UD. Eka Taruna Madiun). Vol.2 No.2 Jurnal Emba.

Pratama, I Putu Agus Eka, 2014. Sistem Informasi dan Implementasinya. Bandung :Informatika Bandung

Raharjo, Budi. 2011. Belajar Otodidak Membuat Database Menggunakan MySQL. Bandung : Informatika Bandung

Tata Sutabri. 2012. Analisis Sistem Informasi. Yogyakarta: Andi

Tohari, Hamim. 2013. Analisis Serta Perancangan Sistem Informasi Melalui Pendekatan UML. Yogyakarta : Andi

Yakub. 2012. Pengantar Sistem Informasi, Yogyakarta: Graha Ilmu

Wahyudi, Rudi. 2015. Analisis Pengendalian Persediaan Barang Berdasarkan Metode EOQ Di Toko Era Baru Samarinda. No. 2 Vol. 1 Jurnal Emba 